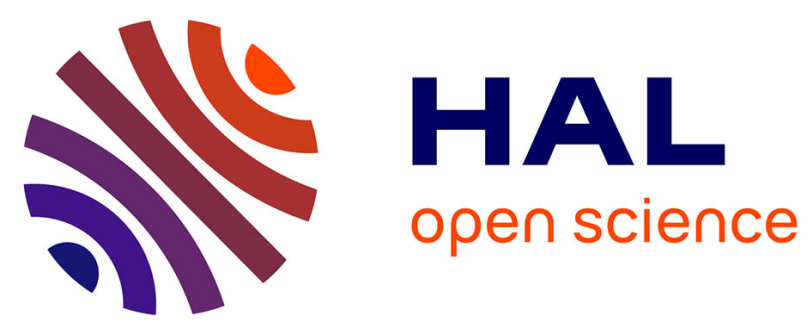

\title{
Caligonella saboorii n. sp. (Acari: Trombidiformes: Caligonellidae) from western Iran
}

\author{
M. Ahmad Hoseini, M. Khanjani, S. Javadi Khederi
}

\section{To cite this version:}

M. Ahmad Hoseini, M. Khanjani, S. Javadi Khederi. Caligonella saboorii n. sp. (Acari: Trombidiformes: Caligonellidae) from western Iran. Acarologia, 2014, 54 (4), pp.473-478. 10.1051/acarologia/20142142 . hal-01565746

\section{HAL Id: hal-01565746 \\ https://hal.science/hal-01565746}

Submitted on $20 \mathrm{Jul} 2017$

HAL is a multi-disciplinary open access archive for the deposit and dissemination of scientific research documents, whether they are published or not. The documents may come from teaching and research institutions in France or abroad, or from public or private research centers.
L'archive ouverte pluridisciplinaire HAL, est destinée au dépôt et à la diffusion de documents scientifiques de niveau recherche, publiés ou non, émanant des établissements d'enseignement et de recherche français ou étrangers, des laboratoires publics ou privés.

\section{(ㅇ)(1) $\$$}

Distributed under a Creative Commons Attribution - NonCommercial - NoDerivatives $\mid 4.0$ 


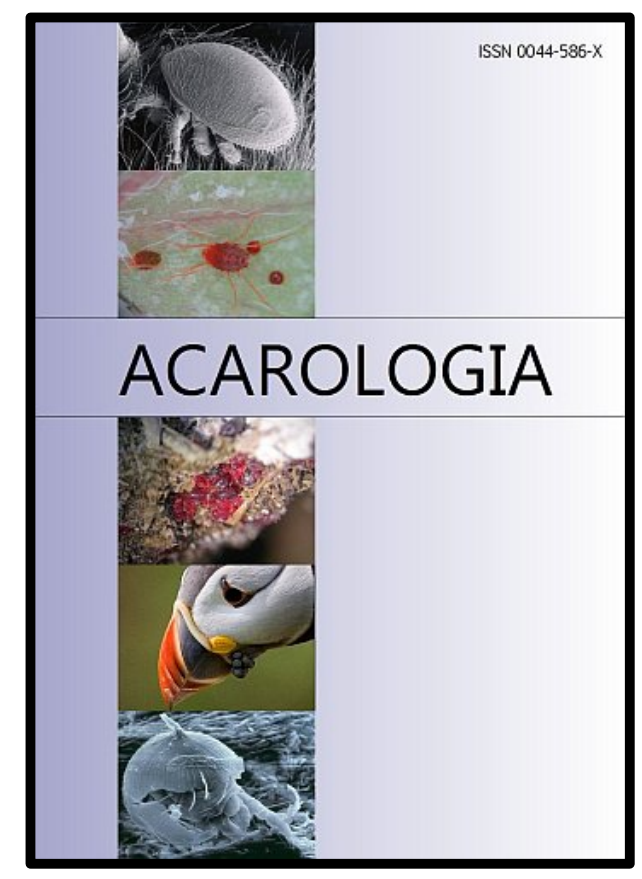

\section{ACAROLOGIA}

A quarterly journal of acarology, since 1959

Publishing on all aspects of the Acari

All information:

http://www1.montpellier.inra.fr/CBGP/acarologia/ acarologia@supagro.inra.fr

\section{OPEN ACCESS}

\section{Acarologia is proudly non-profit, with no page charges and free open access}

Please help us maintain this system by encouraging your institutes to subscribe to the print version of the journal and by sending us your high quality research on the Acari.

Subscriptions: Year 2017 (Volume 57): $380 €$ http://www1.montpellier.inra.fr/CBGP/acarologia/subscribe.php

Previous volumes (2010-2015): $250 € /$ year (4 issues)

Acarologia, CBGP, CS 30016, 34988 MONTFERRIER-sur-LEZ Cedex, France

The digitalization of Acarologia papers prior to 2000 was supported by Agropolis Fondation under the reference ID 1500-024 through the « Investissements d'avenir » programme

(Labex Agro: ANR-10-LABX-0001-01)
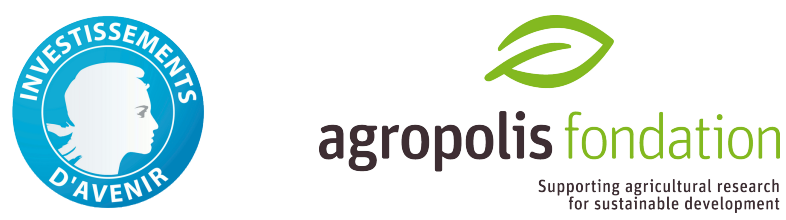

Acarologia is under free license and distributed under the terms of the

Creative Commons-BY-NC-ND which permits unrestricted non-commercial use, distribution, and reproduction in any medium, provided the original author and source are credited. 


\section{CALIGONELLA SABOORII N. SP. (ACARI: TROMBIDIFORMES: CALIGONELLIDAE) FROM WESTERN IRAN}

\section{Mohammad AHMAD HoseInI, Mohammad KHANJANI* and Saeid JAVADI KHEDERI}

(Received 17 September 2014; accepted 14 October 2014; published online 19 December 2014)

Abstract - A new species of the genus Caligonella Berlese, 1910 (Acari: Trombidiformes: Caligonellidae), C. saboorii n. sp. is described and illustrated. This new species was collected from soil and litter under a walnut tree, Juglans regia L. (Juglandaceae) in Khorramabad, Lorestan Province, Southwestern Iran. A key to all known species of the genus Caligonella is provided.

KEYWORDS — predatory mite; free-living; walnut tree; Khorramabad

\section{INTRODUCTION}

The family Caligonellidae was erected by Grandjean (1944) based on genus Caligonella, with C. humilis (Koch, 1838) as type species. Members of this family are small, reddish in life, free-living and can feed on small arthropods. They are often found in various habitats such as soil, leaf litter and bark of trees, moss, storehouses and bird nests (Summers and Schlinger 1955; Meyer and Ueckermann 1989; Fan 2000; Doğan 2003; Ahaniazad and Bagheri 2012; Akyol and Koç 2012). This family currently comprises five genera, of which the genus Caligonella currently contains 9 known species namely: C. $h u-$ milis (Germany), C. afroensis (Meyer and Ueckermann 1989) (South Africa), C. claviparma (Meyer and Ueckermann 1989) (South Africa), C. scutovata (Meyer and Ueckermann 1989) (South Africa), C. geonoma (Meyer and Ueckermann 1989) (South Africa), C. tunxiensis (Hu and $\mathrm{Hu}$ 1997) (China), C. venusta (Khaustov and Kuznetsov 1997) (Ukraine), C. tunica Fan 2000 (China), C. haddadi Bagheria et al. 2013 (Iran). In this study a tenth species of the genus is described.

\section{MATERIALS AND METHODS}

The specimens were collected from soil and litter under Walnut tree, Juglans regia L. (Juglandaceae), in Khorramabad vicinity (Lorestan province), Southwestern Iran. The mites were mounted directly in Hoyer's medium on microscopic slides. The slides were dried at $50^{\circ} \mathrm{C}$ in an oven, sealed with nail polish and examined under an Olympus BX51 Differential Interference Contrast microscope (DIC). Drawings were made with a camera lucida. The terminology, the setal notations and leg chaetotaxy used in the description of the new species follow that of Kethley (1990). All measurements are in micrometers. The measurements 
of the holotype are followed by the variations in the paratypes. A key to species of the genus Caligonella, based on females is provided.

Family Caligonellidae Grandjean, 1944 Genus Caligonella Berlese1910 Type species - Caligonella humilis (Koch, 1838) = Stigmaeus humilis Koch, 1838 Genus. Diagnosis - Relatively small, soft-bodied mites, dorsal shields absent or present, with two pairs of eyes. Stylophore bullet-shaped; fixed digits (spinae) undeveloped, at least not present as slender, spinous processes; peritremata arise on anterior tip of stylophore, terminate on its dorsal surface. Palpus stubby, total length not exceeding that of femur I. Claw small in relation to palptibia (Summers and Schlinger 1955).

\section{Key to the species of the genus Caligonella (Females).}

1. Dorsal shield present .................. 2

— Dorsal shield absent.................... 3

2. Anal covers with one pair of setae ...C. scutovata - Anal covers with two pairs of setae................................ C. claviparma

3. Anal covers with three pairs of setae .. C. venusta - Anal covers with one pair of setae ...........4

4. Genu II with a solenidion............... tunica

— Genu II without a solenidion ................ 5

5. Solenidia on tibia I equal in length............ C. geonoma

- Outer solenidion on tibia I longer than inner solenidion ..............................6 6

6. Venter of idiosoma with shield between coxae............................... afroensis - Venter of idiosoma without shield between coxae................................. 7

7. Outer solenidion on tibia I two times longer than inner solenidion........................... 8 — Outer solenidion on tibia I more than two times longer than inner solenidion 9

8. Solenidion on tarsus I longer than outer solenidion on tibia I and two times longer than the solenidion on tarsus II ..................... humilis - Solenidia on tarsus I-II and outer solenidion on tibia I are equal in length ........... C. saboorii $\mathbf{n} . \mathbf{s p}$.

9. Outer solenidion on tibia I three times longer than inner solenidion, Solenidia on tarsus I and tarsi II subequal in length...............C. haddadi — Outer solenidion on tibia I four times longer than inner solenidion, Solenidion on tarsus I obviously longer than solenidion on tarsus II .... C. tunxiensis

\section{Caligonella saboorii n. sp. Ahmadhoseini and Khanjani (Figs. 1 - 2)}

Diagnosis - Dorsal and venter of idiosoma without shield; outer solenidion on tibia I two times longer than inner one; solenidia on tarsi I and II and outer solenidion on tibia I are equal in length; dorsum with three pairs of cupules.

Female $(n=4)$ - Measurements of holotype: total length of body (including gnathosoma) 420 (400 - 415), length of body (excluding gnathosoma) 315 (305 - 320), width 180 (170 - 185).

Dorsum (Fig. 1a) - Dorsal integument entirely with simple striations, prodorsum without shield and with 11 pairs of subequal setae; one pair of eyes and a pair of post ocular bodies $(P o b)$ present laterally between setae sci and sce. Integument with three pairs of dorsolaterally cupules, $i a$ located behind post ocular bodies, im antero-lateral to setae $d 1$ and ip potero-lateral to setae $f 1$, anal opening posteriorly, with one pair of pseudanal setae (ps1). All dorsal setae are simple, length of dorsal setae as follows: vi $20(18-20)$, ve $26(24-25)$, sci $22(20-22)$, sce $20(19-21), c 120(18-21), c 220(19-20), d 118$ $(19-20)$, e1 $18(17-18), f 1=h 1=h 218(17-18)$; distances between dorsal setae: vi-vi $27(24-28)$, ve-ve 120 (116-125), vi-ve $63(58-65)$, sci-sci $49(48-53)$, sce-sce $175(155-180)$, sci-sce $85(80-87)$, ve-sci 34 $(27-36), c 1-c 135(29-32), c 1-c 250(46-52), c 2-c 2$ 

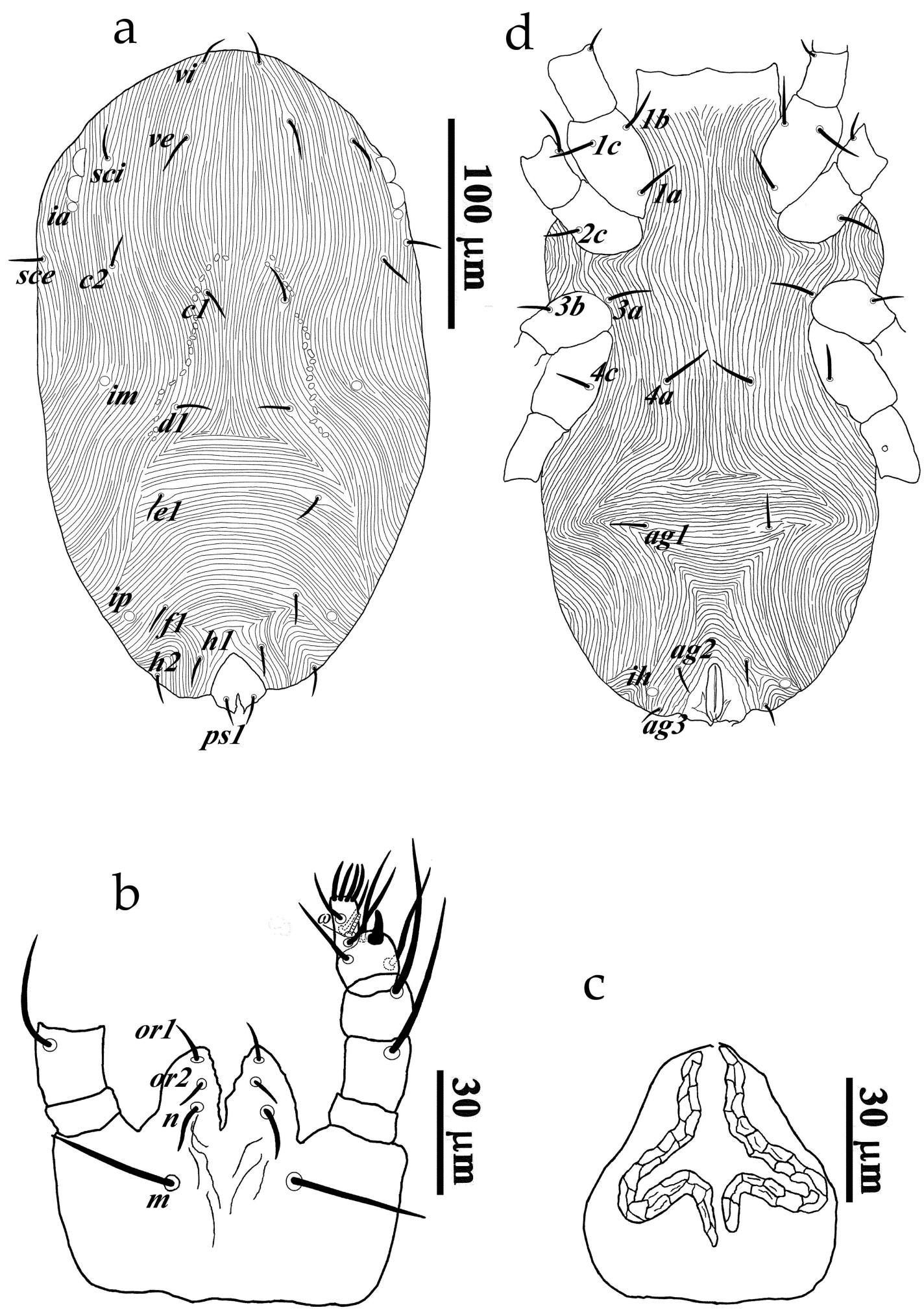

FIGURE 1: Caligonella saboorii n. sp. (Female): a - Dorsal view, b - Gnathosoma, c - Peritreme, d - Ventral view. 

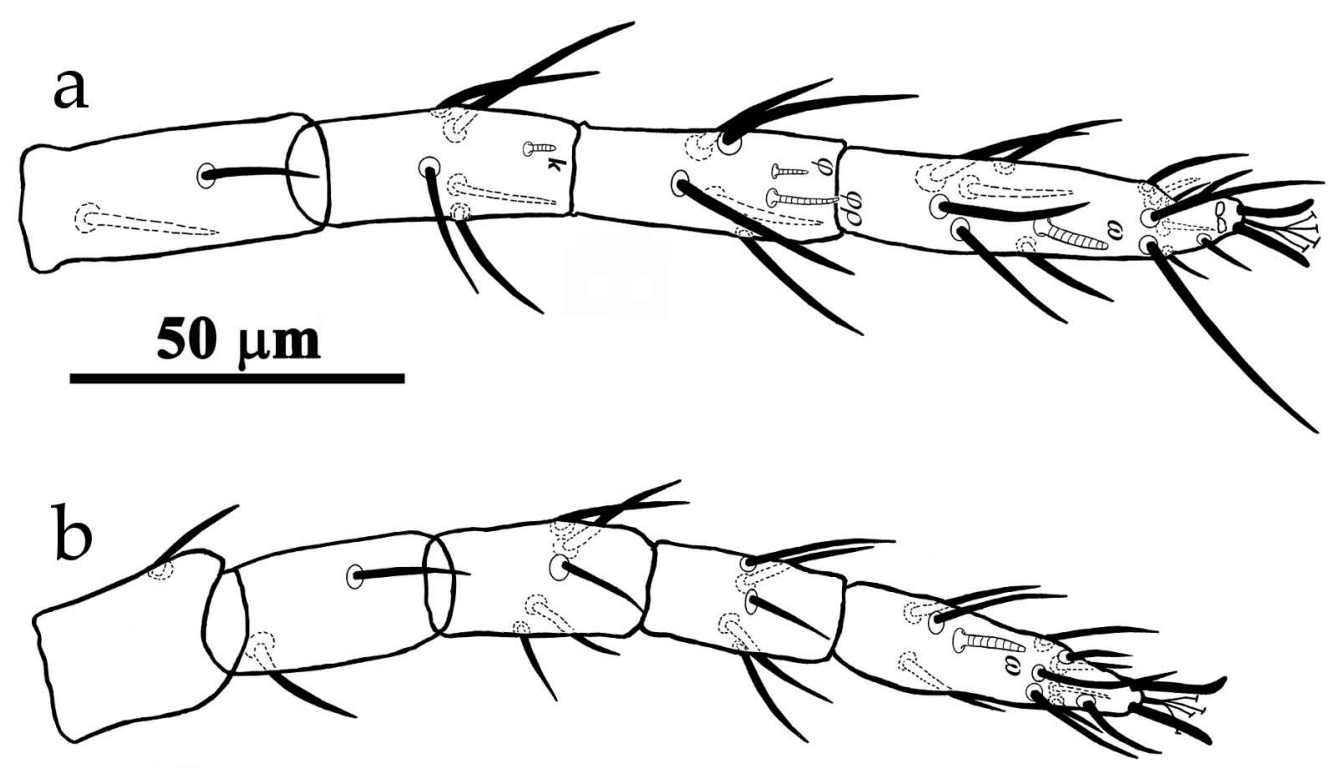

$50 \mu \mathbf{m}$

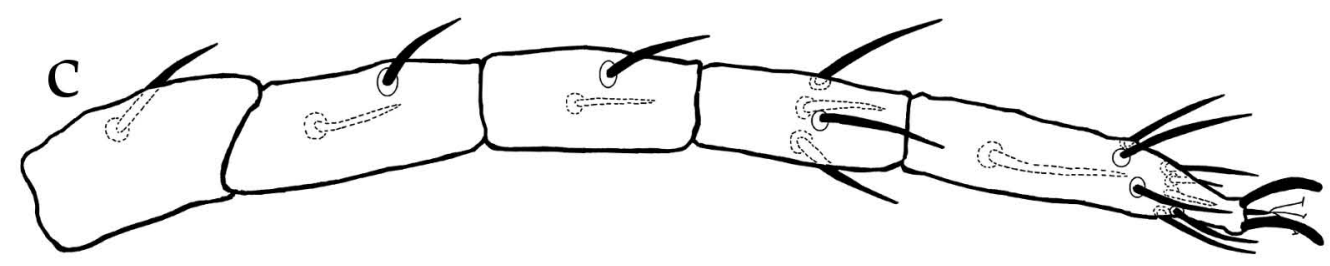

$50 \mu \mathrm{m}$

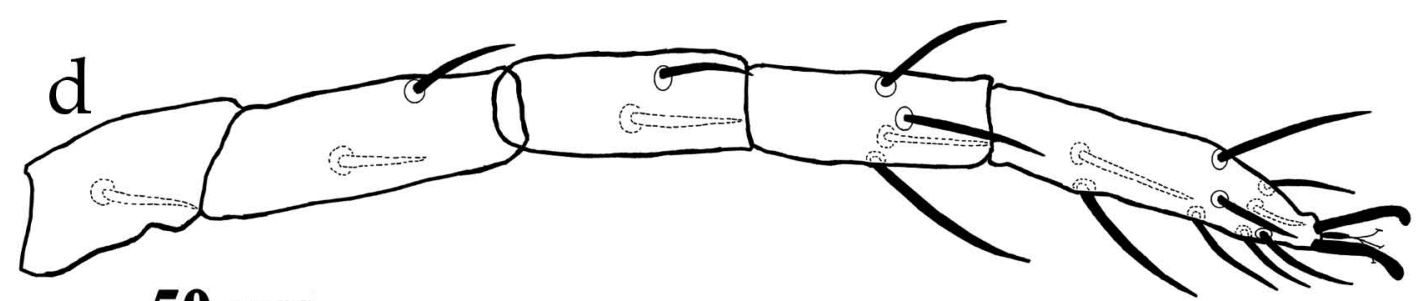

$50 \mu \mathrm{m}$

FIGURE 2: Caligonella saboorii n. sp. (Female): a - Leg I, b - Leg II, c - Leg III, d - Leg IV. 
124 (117 - 127), c1-1 52 (47 - 54), d1-d1 50 (52 - 55), d1-e $40(37-40)$, e1-e1 $75(68-74)$, e1-f1 $50(43-51)$, f1-f1 $63(57-68), f 1-h 130(28-30), f 1-h 231(28-$ 32), h1-h1 24 (21 - 23), h1-h2 29 (27 - 30), h-h2 52(43 - 47). The ratio of dorsal setae as follows: vi/vi-vi $0.74(0.75-0.89), c 1 / c 1-c 10.57(0.62-0.65), d 1 / d 1-d 1$ $0.36(0.36-0.36), e 1 / e 1-e 10.24(0.22-0.25), f 1 / f 1-f 1$ $0.26(0.25-0.29), h 1 / h 1-h 10.75(0.73-0.80), h 2 / h 2-$ h2 $0.35(0.38-0.39), h 1 / h 21.00(0.94-1.00), c 1-c 1$ : d1-d1: e1-e1: f1-f1:(0.47 - 0.55): $(0.79-0.91)$ : $(1.08-$ 1.19): (1.00).

Gnathosoma (Figs. 1b-c) - Chelicerae with proximal components completely fused in midline, forming bullet-shaped stylophore; peritremes confined to dorsal surface of stylophore, with 24-26 chambers on each side (Fig. 3). Palpi five segmented, palp tarsus distally with four eupatidia + one solenidion $5(4-5)$ long + three setae, palp tibia with three setae and one small claw 6 (5-6); palpgenu and palpfemur each with one seta (Fig. 2). Subcapitular setae $m 35(34-36), n 13(13-15)$ long, adoral setae or110 (9 - 10), or $11(9-10) ; m-m 30$ $(28-35), n-n 12(12-14)$ and $m-n 18(18-20)$, or1or1 $20(19-20)$, or2-or2 $18(20$ - 21), or1-or2 $8(7-9)$ (Fig.2).

Venter (Fig. 1d) - Ventral surface striated and three pairs of simple setae present, $1 a$ located on coxae I but $3 a$ and $4 a$ located on integument, genital valves without seta, and aggental region with three pairs of setae (ag1-3), one pair of cupules (ih) located lateral to setae $a g 2$ (Fig. 4). Length of ventral setae as follows: la $28(30-31), 1 b 25(23-26), 1 c$ $27(24-26) ; 2 c 19(18-20), 3 a 28(28-29), 3 b 20(17$ - 21), $4 a 22(20-21), 4 b 21(20-22)$, ag1 $22(21-24)$, ag2 $16(17-18)$, ag3 14 (13 - 15). Distances: ag1-ag1 60 (55 - 63), ag2-ag2 32 (28 - 31), ag3-ag3 43 (38 45), ag1-ag2 65 (63-68), ag2-ag3 29 (30-32). Anal valves in dorsal position and with one pair of setae ps1 15 (14-16).

Legs (Figs. 2) - Leg measurements are from coxa to pretarsus; leg I 280 (270 - 285); leg II 212 (210 - 215); leg III 220 (212 - 226), leg IV 253 (245 - 250); Setal formulae of leg segments as follows: coxae 3-1-2-1; trochanters 1-1-1-1; femora 2-22-2; genua $5+1 \kappa-5-2-2$; tibiae $5+1 \varphi+1 \varphi \rho-5-4-4$; tarsi $15+1 \omega-11+1 \omega-9-9$ (Figs. 5-8). Outer solenidion of tibia I $(\varphi \rho) 11(10-11)$ twice as long as inner solenidion $(\varphi) 5(4-5)$; solenidion on tarsus I $10(10-11)$, solenidion on tarsus II $10(10-10)$.

Differential diagnosis - Caligonella saboorii $\mathrm{n}$. sp. resembles $C$. haddadi and $C$. humilis by having the same leg setal formulae but differs from $C$. haddadi by three main characters: (1) the length of dorsal setae in new species $(17-26)$ longer than those C. haddadi (14-17); (2) the outer solenidion of tibia I two times as long as inner solenidion in C. saboorii $\mathbf{n}$. sp. instead of three times longer than inner solenidion in C. haddadi; (3) the outer solenidion on tibia I $(10-11)$, solenidion on tarsus I $(10-11)$ and solenidion on tarsi II $(10-10)$ are equal in length in new species whereas outer solenidion on tibia I $(15-16)$, longer than solenidion on tarsus I $(11-12)$ and solenidion on tarsus II $(10-10)$ in C. haddadi. The new species shares with $C$. humilis the identical setal formulae of legs and one pair of pseudanal setae but can readily be distinguished from the latter by: (1) the length of dorsal setae in new species (17 - 26) longer than those C. humilis (13); (2) the outer solenidion on tibia I and solenidion on tarsus I are equal in length versus outer solenidion on tibia I shorter than solenidion on tarsus I in C. humilis; (3) The solenidion on tarsus I and solenidion on tarsus II are equal in length in the new species whereas two times longer than on tarsus II in C. humilis.

Type materials - The holotype female and three paratype females were collected from soil and litter under Walnut tree, Juglans regia L. (Juglandaceae) in Khorramabad vicinity Lorestan province $\left(33^{\circ} 56^{\prime} \mathrm{N}\right.$, $48^{\circ} 39^{\prime}$ E, a.s.l. $\left.1703 \mathrm{~m}\right), 8$ July, 2012, by Mohammad Ahmad Hoseini. The holotype female and two paratype females are deposited in the Collection of the Acarology Laboratory, University of BuAli Sina, Hamedan, Iran. One paratype female, will be deposited in the mite Section of National Collection of Arachnida, Plant Protection Research Institute, Pretoria, South Africa.

Etymology - This species is named in honor of Prof. Alireza Saboori, Department of Plant Protection, College of Agriculture, Tehran University, Karaj, Iran. 


\section{REFERENCES}

Ahaniazad M., Bagheri M. 2012 - A new species of the genus Molothrognathus Summers and SchiiInger (AcariI: Trombidiformes: Caligonellidae) from Iran Acarologia, 52(4): 373-376.

Akyol M., Koç K. 2012 - A new species and two records of the family Caligonellidae (Acari: Raphignathoidea) from Turkey - Int. J. Acarol, 38(1): 40-45. doi:10.1080/01647954.2011.583275

Bagheri M., Maleki N., Changizi M. 2013 - On Caligonellid mites (Acari: Trombidiformes: Caligonellidae) of Iran: description of two new species - Int. J. Acarol., 39(8): 632-637. doi:10.1080/01647954.2013.864331

Berlese A. 1910 - Acari nuovi - Manipulus V. Redia, 6(2): 199-214

Doğan S. 2003 - On Caligonellid mites from Turkey (Acari: Caligonellidae) - Arch. Sci. Genève, 56: 6367.

Fan Q-H. 2000 - A phylogenetic analysis of the family Caligonellidae (Acari: Prostigmata) with descriptions of two new species - Acta Entomol. Sinica, 43: 421428.

Grandjean F. 1944 - Observations sur les acariens de la famille des Stigmaeidae - Arch. Sci. Phys. Nat., 26: 103-131.

Hu C., Hu S. 1997 - A new species of genus Caligonella Berlese from China (Acari: Caligonellidae) - Entomol. Sinica, 4(1): 35-37.
Kethley J. 1990 - Acarina: Prostigmata (Actinedida) In: Dindal, DL, editor. Soil biology guide - New York (NY), Wiley, p. 667-756.

Khaustov A.A., Kuznetzov N.N. 1997 - Raphignathoid mites (Acariformes, Raphidognathoidea) of NorthEastern Ukraine, with the description of a new species of the genus Caligonella - Vestn. Zool., 31(1- 2): 80-83.

Koch C.L. 1835-1844 — Deutschlands Crustaceen, Myriapoden und Arachniden - Ein Beitrag zur Deutschen Fauna: 1/ 40, (Herrich-Schaffer, Regensburg).

Meyer (Smith) M.K.P., Ueckermann E.A. 1989 - African Raphignathoidea - Entomol. Mem. Dep. of Agric. Wat. Supply Repub. S. Afri., 74: 1-58.

Summers F.M., Schlinger E.I. 1955 - Mites of the family Caligonellidae (Acari) - Hilgardia, 23: 539-561. doi:10.3733/hilg.v23n12p539

\section{COPYRIGHT}

(c) EY-Nc-ND Ahmad Hoseini M. et al. Acarologia is under free license. This open-access article is distributed under the terms of the Creative Commons-BY-NC-ND which permits unrestricted non-commercial use, distribution, and reproduction in any medium, provided the original author and source are credited. 